\title{
Farmers' Adoption of System of Rice Intensification in Chanchaga Local Government Area of Niger State, Nigeria
}

\author{
${ }^{* 1}$ T. H. Aliyu, ${ }^{20}$. G. Bello, ${ }^{3}$ L. K. Olatinwo, ${ }^{4}$ K. F. Omotesho, ${ }^{4}$ L. L. Adefalu and ${ }^{4}$. Garba \\ ${ }^{1}$ Department of Crop Protection, Faculty of Agriculture University of Ilorin, Nigeria \\ 2Department of Agricultural Economics and Extension, Federal University Dutse, Jigawa State-Nigeria \\ ${ }^{3}$ Department of Agricultural Economics and Extension Services, Kwara State University, Malete-Nigeria \\ ${ }^{4}$ Department of Agricultural Extension and Rural Development, University of Ilorin-Nigeria
} [ ${ }^{*}$ Corresponding author: Email: aliyutaiyehussein@yahoo.com]

\section{ABSTRACT}

The study evaluated the adoption of System of rice intensification (SRI) among rice farmers in Chanchaga Local Government Area of Niger State, Nigeria. A 3-stage sampling technique was used to collect data for the study through a structured questionnaire and interview schedule administered to 200 rice farmers. The results indicated that the majority of the farmers were males (83.0\%) and married (68.5\%) with no formal education (50.5\%). Mean age was 44.1 years, household size was 8.8 persons, farming experience of 16 years, average monthly income was N590,000.00 and average farm size was 1.7 ha. The most adopted SRI production practice was fertilizer and herbicide application (100.0\%), planting depth (91.5\%) manual land cultivation and planting method (91.0\%). The respondents were at different stages of adoption with accelerating growth, rotary weeding and use of organic fertilizer having positive adoption index of 0.972 , 0.970 and 0.601 , respectively. Level of adoption of SRI technologies was low (34.5\%) with a positive perception. Major constraints to SRI technologies were high labor $(\bar{x}=3.27)$, non-awareness of SRI technologies $(\bar{x}=3.14)$ inadequate understanding of SRI $(\bar{x}=2.89)$. The profitability of SRI in rice cultivation was higher compared to the conventional method. Therefore, the provision of more training and demonstration programmes and input subsidy should be encouraged to boost adoption of SRI for improved rice production.

Keywords: Rice Intensification, Farming activities, Training, Chanchaga, System, Niger State.

\section{INTRODUCTION}

Rice (Oryza sativa L.) is one of the most important cereal crops all over the world and it is grown in a wide range of climatic zones. Rice is the staple food for nearly half of the world's population, most of who live in developing countries. The crop occupies one-third of the world's total area planted to cereals and also provides 35 to $60 \%$ of the calories consumed by 2.7 billion people worldwide (Tayefe, et al., 2014). Rice consumption has risen tremendously at about $10 \%$ per annum and is the most consumed staple food by Nigeria's over 174 million people across states and geo-political zones (Terwase and Madu, 2014). However, there is lopsidedness in the level of production of rice in Nigeria as compared to its consumption pattern (Omofonmwan and Kadiri, 2017). System of rice intensification (SRI) is a methodology for increasing the productivity of irrigated rice by changing the management of plants, soil, water, nutrients and transplanting young seedlings at a wider spacing (Fernandes and Uphoff, 2002).

The literature on agriculture has highlighted two major driving factors behind successful agricultural technology adoption in developing countries. These are: (1) the availability and affordability of new agricultural technologies and (2) farmers' expectations of long-term profitability promised by the new technology (Foster and Rosenzweig, 1995). These factors can be further categorized into three groups namely: economic factors, social factors and institutional factors. The economic factors included farm size, cost of adoption, access to credit, expected benefits from the adoption and the off-farm income generation activities. The social factors included the age of farmers, the level of education and gender. The 


\section{Aliyu et al. Farmers' Adoption of System of Rice Intensification in Chanchaga...}

institutional factors included access to extension services (Chi and Yamada, 2002).

Niger state in Nigeria emerged and remains a major contributor to agricultural productivity in the country. Despite being a major hub with vast acreages and the third-largest rice producing state of the nation, it is faced with several sectorial challenges impeding rice farming. Yet very little has been done over the years to assess the trends in local rice production to gauge yield potentials and develop new models for improved decision-making capability (Merem et al., 2017). SRI practice in many tropical and subtropical countries have shown the significance of SRI methods with respect to increasing grain yield. The main objective of this study was to assess farmers' adoption of SRI and identify the constraints to the adoption of SRI in Chanchaga Local Government Area of Niger State, Nigeria. Specifically, the study aimed to: (i) describe the socio-economic characteristics of rice farmers in the study area and (ii) assess the rate, level of adoption and constraints of SRI by farmers in the study area.

\section{MATERIALS AND METHODS \\ Study Area}

The study was carried out in Chanchaga Local Government Area (LGA) of Niger State. Niger State is located within the Guinea Savannah ecological zone of Nigeria. Some of the crops grown in Niger State include yam, cotton, maize, sorghum, millet, soybean, cowpea, rice and groundnut. The State has 25 LGAs with three Agricultural Zones (Sheshi and Usman, 2018).

\section{Sampling techniques and data collection}

A multi-stage (3-stage) sampling technique was employed in the study. The first stage was the purposive selection of a LGA in Niger State with a large population of farmers involved in rice production. The second stage involved a random selection of 8 out of the 11 wards in the LGA while the third stage involved a random selection of 25 respondents from each ward to give a sample size of 200 respondents. Primary data were obtained from information obtained by the structured questionnaires and secondary data accessed through government publications, websites, books, journal articles, internal records and past publications.

\section{Statistical Analysis}

Descriptive statistics such as frequency counts, percentages, mean, standard deviation and Likert type scale were used in analyzing the data. The constraints to the adoption of SRI were analyzed using a four-point Likert type scale with 2.5 as mean $(\bar{x})$ decision rule. Cumulative values of above $\bar{x}=2.5$ imply major constraint while below implies not a constraint. This was scaled as strongly agreed $=4$, agreed $=3$, disagreed $=2$ and strongly disagreed $=1$. Rate of adoption was determined by the total number of adopters over the sample size expressed as a percentage as well as the mean value. The respondents' adoption stages of SRI techniques were examined against compliance with recommended practices. According to Rogers' (2003) classification, there are five stages in the adoption of innovation by clientele in any social system. These stages are awareness $(A=1.00)$, interest $(I=2.00)$, evaluation $(E=3.00)$, trial $(T=4.00)$ and adoption $(A D=5.00)$. Therefore, in investigating the adoption of SRI a mean average was determined as follows: $5+4+3+2+1 / 5=3$. It implies that variables with positive adoption are those with adoption index, $\overline{\mathrm{x}} \mathrm{n}$ of $\geq 0.6$.

\section{RESULTS AND DISCUSSION \\ Socioeconomic Characteristics of Respondents}

Table 1 shows some socioeconomic attributes of the respondents. The results revealed that majority of the farmers were males $(81.5 \%)$ probably because of the tedious work of managing rice farms from land/field preparation to processing. This result is in agreement with the findings of Carr (2008) that implied male domination of farming activities. On the contrary, it was posited by AFDB (2000) and FAO (2011) that the combined time burden of household chores and farm work may have been too rigorous for women and affirmed that gender 
disparity weakens women's rights to land and their position in accessing financial resources where collaterals are needed. Majority of respondents were within the age range of 30 $50 y e a r s(73.5 \%)$ and clientele's mean age is 44.1 years. The finding suggests respondents were in their productive years, which could be instrumental to the adoption of improved technology as suggested by Sheik et al. (2003). A larger proportion was married (68.5\%) with a mean household size of 9 persons $(75.0 \%)$. According to Akinbile (2007), marriage confers responsibility on respondents to cater for their households through the various livelihood activities they are engaged. The large household size in the study will provide adequate labour for farming activities as a household with a large size tended to attach greater importance to food security than those with small size. These findings have implication for the adoption level of technologies in the study area as reported by Folorunso and Okoroji (2015) and Ejechi et al., (2016).

The result showed slightly above average $(50.5 \%)$ of respondents have no formal education while only about $1 / 3(28.0 \%)$ had only primary education which implied that the respondents were not educated. Agwu and Anyanwu (1996) reported that an increase in education of farmers positively influences the adoption of improved practices. A higher percentage of the respondents $(38.5 \%)$ had the farming experience of $11-20$ years. Farming experience according to Hassan and Nhemachena (2008) increases the probability of uptake of adoption measures. The farm size of $93.5 \%$ of respondents is less than 3 ha with mean of $1.7 \mathrm{ha}$, an indication that small-scale family managed farm units are mostly in use by farmers in the study area; which may in turn limit investment in technology adoption and output level.

The average annual income of respondents is less than or equal to one million (97.0\%) as well as their degree of cosmopoliteness indicating that respondents hardly travel out of their immediate environment. Farmers' cosmopoliteness according to Olowu et al. (1990) is a significant determinant of the adoption of new technologies. Islam et al. (2007) further asserted that farmers with higher expenditure had better economic and social status in the community.

On assess to SRI training on rice production, the majority $(67.0 \%)$ claimed that they had passed through the training among the clientele. This implies that a significant proportion (2/3) of the respondents were aware and trained on the SRI technologies. This finding is in agreement with Bassey (2016) that reported SRI adoption rate of $50 \%$ by rice farmers in south-south Nigeria.

\section{Management Practices Adopted by Rice Farmers}

Table 2 shows the management practices adopted by rice farmers in the study area. The Table shows that all the respondents practiced fertilizer and herbicides application (100.0\%), a greater proportion (91.5\%) of the farmers put into practice planting depth while the use of manual land cultivation and planting method is also in vogue $(91.0 \%)$. A significant percentage $(88.0 \%)$ adopted plant spacing too. However, on the contrary only, few of the respondents do engage in the following management practices; tractor land ploughing 
Aliyu et al. Farmers' Adoption of System of Rice Intensification in Chanchaga...

Table 1: Distribution of the respondents based on the socio-economic characteristics

\begin{tabular}{|c|c|c|c|}
\hline VARIABLES & FREQUENCY & PERCENTAGE & $\bar{x} \pm$ SD \\
\hline \multicolumn{4}{|l|}{ Age (Years) } \\
\hline$\leq 30$ & 1 & 0.8 & \multirow[t]{7}{*}{$44.1 \pm 6.6$} \\
\hline $30-40$ years & 79 & 39.5 & \\
\hline $41-50$ years & 68 & 34.0 & \\
\hline$\geq 51$ & 53 & 26.5 & \\
\hline \multicolumn{3}{|l|}{ Sex } & \\
\hline Female & 37 & 18.5 & \\
\hline Male & 163 & 81.5 & \\
\hline \multicolumn{4}{|l|}{ Marital Status } \\
\hline Single & 53 & 26.5 & \\
\hline Married & 137 & 68.5 & \\
\hline Separated & 0 & 0.0 & \\
\hline Divorced & 0 & 0.0 & \\
\hline Widowed & 10 & 5.0 & \\
\hline \multicolumn{4}{|c|}{ Household Size (No of persons) } \\
\hline$\leq 5$ & 56 & 28.0 & \multirow[t]{10}{*}{$8.8 \pm 3.0$} \\
\hline $6-10$ & 94 & 47.0 & \\
\hline $11-15$ & 19 & 9.5 & \\
\hline $16-20$ & 18 & 9.0 & \\
\hline \multirow{2}{*}{\multicolumn{3}{|c|}{ Educational Qualification }} & \\
\hline & & & \\
\hline No formal education & 101 & 50.5 & \\
\hline Primary Education & 56 & 28.0 & \\
\hline Secondary Education & 33 & 16.5 & \\
\hline Tertiary Education & 10 & 5.0 & \\
\hline \multicolumn{4}{|c|}{ Farming Experience (Years) } \\
\hline$\leq 10$ & 58 & 29.0 & \multirow[t]{4}{*}{$16 \pm 4.4$} \\
\hline $11-20$ years & 77 & 38.5 & \\
\hline $21-30$ years & 60 & 30.0 & \\
\hline$\geq 31$ & 5 & 2.5 & \\
\hline \multicolumn{4}{|l|}{ Farm Size (Ha) } \\
\hline$\leq 3$ & 187 & 93.5 & \multirow[t]{3}{*}{$1.7 \pm 1.3$} \\
\hline 4-6 & 13 & 6.5 & \\
\hline$\geq 7$ & 0 & 0.0 & \\
\hline \multicolumn{4}{|c|}{ Average Annual Income (Naira/million) } \\
\hline$\leq 1$ & 194 & 97.0 & \multirow[t]{8}{*}{ 0.59million } \\
\hline 2-4 & 5 & 2.5 & \\
\hline$\geq 5$ & 1 & 0.5 & \\
\hline \multicolumn{3}{|c|}{ Assess to SRI Training } & \\
\hline Yes & 134 & 67.0 & \\
\hline No & 66 & 33.0 & \\
\hline \multicolumn{3}{|c|}{ Degree of Cosmopolitness } & \\
\hline Yes / No & 36 & 18.0 & \\
\hline
\end{tabular}


$(9.0 \%)$, seed selection before planting/after processing $(7.0 \%)$ and pesticide application $(6.5 \%)$ while none of the respondents engages in irrigation and storage of rice harvest using modern storage equipment $(0.0 \%)$. This finding is in agreement with Akintayo et al. (2010) that reported rice farmers in Niger state employed sub-optimal recommended management practices; seed rate, fertilizers and agrochemicals for weed control. This could be responsible for the low yields obtained by rice farmers in the zone as also agreed by Coulibaly et al. (2020).

\section{Respondents' Adoption Stages of System Rice Intensification}

It can be seen from Table 3 judging from the mean value $(\bar{x})$ and the adoption index $(\bar{x} / n)$ that, the respondents were at the awareness stage of adoption for early transplanting ( $\bar{x}=1.210$; $\bar{x} / n=0.242$ ) and spacing of plant wider apart in a square pattern $(\bar{x}=1.180 ; \bar{x} / n=0.236)$. In addition, adoption was at interest stage for both planting of one seedling per hole on the field $(\bar{x}=1.760$; $\bar{x} / n=0.352$ ) and intermittent watering to increase wet and dry soil condition apart from continuous flooding $(\bar{x}=2.085 ; \bar{x} / n=0.417)$. Increased uses of organic fertilizer to enhance soil fertility ( $\bar{x}=3.005$; $\bar{x} / n=0.601$ ) was at the evaluation stage of adoption while accelerating growth under good soil, water and nutrient condition and proper handling ( $\bar{x}=3.960 ; \bar{x} / n=0.792)$ was at the trial stage of adoption of innovation. Only rotary weeding to control weeds and promote soil aeration ( $\bar{x}=4.850 ; \quad \bar{x} / n=0.970)$ was at full adoption stage of the innovation of system rice intensification. Based on adoption index only three variables (increased use of organic fertilizer, rotary weeding and accelerated growth under good soil, water and nutrient respectively were positive, while the remaining four (early transplanting of seedlings, planting of one seedling per hole, spacing of plants wider apart and intermittent water application) were not. This implies that these four variables under the system of rice intensification were not adopted since they have lower adoption index values (i.e. $\bar{x} / n$ less than 0.6 ). Similar findings were also reported by Nath and Das (2017) and Agarwal and Kumar (2017).

Table 2: Distribution of the Respondents based on Management Practices Adopted

\begin{tabular}{lllll}
\hline S/N & RICE MANAGEMENT PRACTICE & FREQUENCY & PERCENTAGE & RANK \\
\hline 1 & Tractor Land ploughing & 18 & 9.0 & $5^{\text {th }}$ \\
2 & Manual land ploughing and planting & 182 & 91 & $3^{\text {rd }}$ \\
3 & Seed selection & 14 & 7.0 & $6^{\text {th }}$ \\
4 & Planting Depth & 183 & 91.5 & $2^{\text {nd }}$ \\
5 & Plant Spacing & 176 & 88.0 & $4^{\text {th }}$ \\
6 & Herbicide Application & 200 & 100.0 & $1^{\text {st }}$ \\
8 & Pesticide Application & 13 & 6.5 & $7^{\text {th }}$ \\
10 & Fertilizer Application & 200 & 100.0 & $1^{\text {st }}$ \\
11 & Irrigation & 0 & 0.0 & $8^{\text {th }}$ \\
12 & Use of modern storage equipment & 0 & 0.0 & $8^{\text {th }}$ \\
\hline
\end{tabular}




\section{Aliyu et al. Farmers' Adoption of System of Rice Intensification in Chanchaga...}

Table 3: Distribution of the Respondents Based on the Stages Involved in the Adoption Process of System of Rice Intensification

\begin{tabular}{|c|c|c|c|c|c|c|c|c|}
\hline VARIABLES & $\bar{A}$ & | & $E$ & $\bar{T}$ & $A D$ & $\overline{\bar{x}}$ & $\bar{x} / n$ & $\bar{D}$ \\
\hline Early Transplanting of Seedlings to open field & 181 & 7 & 5 & 3 & 4 & 1.210 & 0.242 & $\bar{A}$ \\
\hline Planting of one seedling per hole on field & 63 & 129 & 1 & 7 & 0 & 1.760 & 0.352 & I \\
\hline $\begin{array}{l}\text { Spacing of plants wider apart and in a square } \\
\text { pattern }\end{array}$ & 184 & 3 & 7 & 5 & 1 & 1.180 & 0.236 & $A$ \\
\hline $\begin{array}{l}\text { Increased use of organic fertilizer to enhance } \\
\text { soil fertility }\end{array}$ & 4 & 1 & 191 & 3 & 2 & 3.005 & 0.601 & $E$ \\
\hline $\begin{array}{l}\text { Intermittent water application to increase wet } \\
\text { and dry soil conditions instead of continuous } \\
\text { flooding }\end{array}$ & 2 & 189 & 2 & 4 & 3 & 2.085 & 0.417 & I \\
\hline $\begin{array}{l}\text { Rotary weeding to control weeds and } \\
\text { promote soil aeration }\end{array}$ & 3 & 2 & 2 & 8 & 185 & 4.850 & 0.970 & $A D$ \\
\hline $\begin{array}{l}\text { Accelerating growth under good soil, water } \\
\text { and nutrient conditions and proper handling } \\
\text { procedure }\end{array}$ & 2 & 1 & 0 & 197 & 0 & 3.960 & 0.792 & $\mathrm{~T}$ \\
\hline
\end{tabular}

Key: Mean $=\bar{x}$ Adoption Index $=\sum \bar{x}$ and $\mathrm{D}=$ Decision. Awareness (A), Interest (I), Evaluation (E), Trial (T) and Adoption (AD).

Categorization of Level of Adoption of System Rice Intensification (SRI)

Table 4 indicates the level of adoption of System Rice Intensification by rice farmers in Chanchaga community of Niger State, Nigeria. The Table shows that $34.5 \%$ of the respondents have adopted the System of Rice Intensification method, while the majority (65.5\%) of the respondents did not adopt the system. Bassey (2016) found the adoption rate of SRI of 50\% among respondents in Abi LGA of Cross-Rivers State, Nigeria.

\section{Perception of Cost and Reasons for Adopting SRI}

The perceived benefits and cost of adopting SRI are highlighted in Table 5. Majority (64.0\%) of the respondents spent an amount less than 10,000 per hectare on labor for adopting SRI while the remaining $32.0 \%$ of the respondents incurred input cost of $\$ 10,000$ and above $\$ 20,000$, respectively. On input cost, majority $(78.0 \%)$ of the respondents spent less than 10,000 while $22.0 \%$ spent more than 20,001 , which is another factor that determines their adoption of SRI. Based on the perceived benefits of adopting SRI by the respondents, it shows that there is increase in income as expressed by majority of the respondents $(80.0 \%)$. It also saves time and labor required in the entire production $(70.0 \%)$ as well as increased yield of the rice (66.0\%).

Table 4: Distribution of the respondents based level of adoption of system of rice intensification

Variable Frequency Percentage

\begin{tabular}{lll}
\hline $\begin{array}{l}\text { Adoption } \\
\text { of SRI }\end{array}$ & & \\
Yes & 69 & 34.5 \\
No & 131 & 65.5 \\
Total & 200 & 100 \\
\hline
\end{tabular}


Nigerian Journal of Basic and Applied Science (December, 2020), 28(2): 55-63

Table 5: Perceived benefits and costs for adopting SRI

\begin{tabular}{lll}
\hline VARIABLES & FREQUENCY & PERCENTAGE (\%) \\
\hline Labor Cost on 1 ha & & \\
Less than 10,000 & 128 & 64.0 \\
10,000 - 20,000 & 44 & 22.0 \\
Input Cost (\$) & 28 & 14.0 \\
Less than above & & \\
10,000 & 156 & 78.0 \\
F20,001 and above & 36 & 18.0 \\
Factors Determining Adoption & 2 & 8.0 \\
Increased income & & \\
Saves time and labor & 160 & 80.0 \\
Increased crop yield & 140 & 70.0 \\
It gives maximum plant population & 132 & 66.0 \\
\hline
\end{tabular}

The respondents disagreed on the fact that it gives a high plant population (8.0\%) once the normal seed rate is used. Similar findings were reported by Krishnan and Tarnaka (2008).

\section{Respondents' Constraints to the Adoption of SRI}

The constraints of the respondents to the adoption of a system of rice intensification are shown in Table 6 . The results indicate that high labor cost ranked first with mean score of $\bar{x}=$ 3.27 , this was followed by non-awareness of SRI with a mean score of $\bar{x}=3.14$, while inadequate understanding of SRI technologies $(\bar{x}=2.89)$ took the third place. Non-availability of funds $(\bar{x}=2.84)$ was the fourth-ranked constraint. Non-availability of extension agents $(\bar{x}=1.75)$ and non-availability of input materials $(\bar{x}=1.00)$ were not seen as constraints to the respondents in the study area since cumulative average values were below the decision rule mean of $(\bar{x})=2.50$. This supported the work of Johnson and Vijayaragavan (2011).

\section{CONCLUSION}

It can be concluded that although most of the respondents practiced $S R I$ technologies such as fertilizer and herbicide application, however, early planting of seedlings per hole, the spacing of plants and intermittent watering was not adopted by most respondents in the study area. This indicated a low level of SRI technology acceptance, although there was a positive perception of the SRI technologies among the respondents. The constraints of the respondents to the adoption of SRI technologies were high cost, non-awareness and inadequate understanding of SRI technologies. It is therefore, recommended that there should be the provision of more training demonstration programmes and input subsidy to boost the awareness level of the respondents for more adoption of the SRI technologies. 


\section{Aliyu et al. Farmers' Adoption of System of Rice Intensification in Chanchaga...}

Table 6: Distribution of the Respondents based on Constraints to Adoption of SRI

\begin{tabular}{|c|c|c|c|c|c|c|c|}
\hline PROBLEMS & $\begin{array}{l}\text { SA } \\
(4)\end{array}$ & $\begin{array}{c}A \\
(3)\end{array}$ & $\begin{array}{l}\mathrm{DA} \\
(2)\end{array}$ & $\begin{array}{c}\text { SDA } \\
(1)\end{array}$ & CUM & $\overline{\bar{x}}$ & $\mathbf{R}$ \\
\hline Non-awareness of SRI & $\begin{array}{c}84 \\
(344)\end{array}$ & $\begin{array}{c}63 \\
(189)\end{array}$ & $\begin{array}{c}44 \\
(88)\end{array}$ & $\begin{array}{c}7 \\
(7)\end{array}$ & 628 & 3.14 & $2^{\text {nd }}$ \\
\hline $\begin{array}{l}\text { Non-availability of } \\
\text { extension agents }\end{array}$ & $\begin{array}{c}6 \\
(24)\end{array}$ & $\begin{array}{l}28 \\
(84)\end{array}$ & $\begin{array}{c}76 \\
(152)\end{array}$ & $\begin{array}{c}90 \\
(90)\end{array}$ & 350 & 1.75 & $5^{\text {th }}$ \\
\hline $\begin{array}{l}\text { Non-availability of } \\
\text { input materials }\end{array}$ & $\begin{array}{c}93 \\
(372)\end{array}$ & $\begin{array}{c}68 \\
(204)\end{array}$ & $\begin{array}{c}29 \\
(58)\end{array}$ & $\begin{array}{c}10 \\
(10)\end{array}$ & 200 & 1.00 & $6^{\text {th }}$ \\
\hline $\begin{array}{l}\text { Inadequate } \\
\text { Understanding of SRI }\end{array}$ & $\begin{array}{c}75 \\
(300)\end{array}$ & $\begin{array}{c}58 \\
(174)\end{array}$ & $\begin{array}{c}38 \\
(76)\end{array}$ & $\begin{array}{c}29 \\
(29)\end{array}$ & 579 & 2.89 & $3^{\text {rd }}$ \\
\hline High labor cost & $\begin{array}{c}98 \\
(392)\end{array}$ & $\begin{array}{c}70 \\
(210)\end{array}$ & $\begin{array}{c}20 \\
(40)\end{array}$ & $\begin{array}{c}12 \\
(12)\end{array}$ & 654 & 3.27 & 1 st \\
\hline $\begin{array}{l}\text { Non availability of } \\
\text { funds }\end{array}$ & $\begin{array}{c}60 \\
(240)\end{array}$ & $\begin{array}{c}72 \\
(216)\end{array}$ & $\begin{array}{c}47 \\
(94)\end{array}$ & $\begin{array}{c}21 \\
(21)\end{array}$ & 571 & 2.84 & $4^{\mathrm{st}}$ \\
\hline
\end{tabular}

The figures in parentheses are the sum of frequency and the scale Key: CUM = Cumulative, CA = Cumulative average and $\mathrm{R}=$ Ranking.

\section{REFERENCES}

African Development Bank (AfDB) (2000), Gender Policy, AfDB, Abidjan.

Agarwal, P.K., \& Kumar, A. (2017). A socioeconomic study on the pros and cons of the SRI method of paddy cultivation in Ormanjhi block of Ranchi district, Jharkhand, India. Indian Journal of Agricultural Research, 51(1): 74-77.

Agwu, A. E., \& Anyanwu, A.G. (1996). Sociocultural and environmental constraints in implementing the NALDA programme in Southern Nigeria. A case study of Abia and Enugu State. Journal of Agricultural Technology and Education, 2: 68-72.

Akinbile, L. A. (2007). Determinants of productivity level among rice farmers in Ogun State, Nigeria. In African Crop Science Conference Proceedings, 8: 1339-1344.

Akintayo, O.I., Rahji, M.A.Y., Awoyemi, T.T., \& Adeoti, A.I. (2010) Determinants of yield gap in lowland rice production in northcentral. Agrosearch, 11: 1-10.
Bassey, J.I. (2016). Comparative analysis of system of rice intensification and traditional system of rice production in Abi L.G.A, Cross River State, Nigeria. European Journal of Agriculture and Forestry Research, 4(2): 9-23.

Carr, R.E. (2008). Men's crops and women's crops: the importance of gender to the understanding of agricultural and development outcomes in Ghana's central region. World Development, 36: 900-915.

Chi, T.T.N., \& Yamada, R. (2002). Factors affecting farmers' adoption of technologies in farming system: A case study in Omon district, Can Tho province, Mekong Delta. Omonrice, 10: 94-100.

Coulibaly, B., Shixiang, L., \& Wang, Z. (2020). Rice farmer's poverty and its determinants: evidence from Dogofiri village of Office du Niger zone in Mali. Ciência Rural, 50(2): e20190260.

Ejechi, M.E., Onu, A.D., Muogbo, P.C., \& Aboajah, F.N. (2016). Determinants of climate 


\section{Nigerian Journal of Basic and Applied Science (December, 2020), 28(2): 55-63}

change adaptive strategies among small scale yam farmers in Federal Capital Territory, Nigeria. Journal of Agriculture and Social Research, 16(1): 28-36.

Fernandes, E.C.M., \& Uphoff, N. (2002). Summary from conference reports. In: Assessment of the System of Rice Intensification (SRI). Proceedings of an International Conference, Sanya, China, pp. 33-39.

Folorunso, S.T, \& Okoroji, E.O. (2015). Analysis of factors affecting the performance of Samaz 15 Maize Variety among farmers in Riyom Local Government Area of Plateau State, Nigeria. Proceedings of the 29th Annual Conference of Farm Management Association of Nigeria Dutse.

Food and Agriculture Organization (FAO) (2011), State of Food and Agriculture 2010-2011. Women in Agriculture: Closing the Gender Gap for Development, FAO, Rome.

Foster A.D., \& Rosenzweig, M.R. (1995). Learning by doing and learning from others: Human capital and technical change in agriculture. Journal of Political Economy, 103: 1176209.

Hassan, R., \& Nhemachena, C. (2008). Determinants of African farmers' strategies for adapting to climate change: Multinomial choice analysis. African Journal of Agricultural and Resource Economy, 2(1): 68-77.

Islam, M. S., Uddin, M. E., \& Rashid, M. U. (2007). Use of Knowledge system in the rural community in improving livelihood status of the farmers under RDRS. Journal of Agriculture and Rural Development, 5(1\&2): 167-17.

Johnson, B., \& Vijayaragavan, K. (2016). Diffusion of the system of rice intensification (SRI) across Tamil Nadu and Andhra Pradesh in India. Indian Research Journal of Extension Education, 11(3), 72-79.

Krishnan, J., \& Tarnaka, S. (2008). SRI in Tamil Nadu-A status report. Tamil Nadu: GEO Foundation.

Merem, E.C., Twumasi, Y., Wesley, J., Isokpehi, P., Shenge, M., Fageir, S., Crisler, M.,
Romorno, C., Hines, A., Hirse G., Ochai, S., Leggett, S., \& Nwagboso, E. (2017). Analyzing rice production issues in the Niger State area of Nigeria's middle belt. Food and Public Health, 7(1): 7-22.

Nath, D., \& Das, D.K. (2017). Constraints encountered by rice farmers of Tripura in the adoption of the system of rice intensification (SRI) technology. International Journal of Farm Sciences, 7(1): 110-115

Olowu, T. A., lloka, A. I., \& Ekpere, J. A. (1990). Farmers characteristics and adoption of improved cassava varieties in Imo State, Nigeria. Journal of the Nigerian Academy of Science, 2: 93-100.

Omofonmwan, S.I., \& Kadiri, M.A. (2017). Problems and prospects of rice production in central district of Edo State, Nigeria. Journal of Human Ecology, 22(2): 123128.

Rogers, E.M. (2003). Diffusion of innovations (5th ed.). New York: Free Press.

Sheshi, U.I., \& Usman, M. (2018). Increasing rice production through adoption of improved variety in Niger State, Nigeria. Journal of Bangladesh Agricultural University, 16(2): 182-186.

Sheik, A., Rahman, T., \& Yates, C.M. (2003). Logit models for identifying the factors that influence the uptake of new no tillage technologies by farmers in the rice-wheat and cotton-wheat farming systems in Pakistan. Agricultural systems, 75(1): 7995.

Tayefe, M., Gerayzade, A., Amiri, E. and Zade, A. (2014). Effect of nitrogen on rice yield, yield components and quality parameters. African Journal of Biotechnology, 13(1): 91-105.

Terwase, I.T., \& Madu, A.Y. (2014). The impact of rice production, consumption and importation in Nigeria: the political economy perspectives. International Journal of Sustainable Development and World Policy, 3(4): 90-99. 